\title{
PENGELOLAAN BUMN SEBAGAI TRANSFORMASI KEUANGAN PUBLIK MENJADI KEUANGAN PRIVAT DALAM PERSEPEKTIF HUKUM KEUANGAN NEGARA
}

\author{
Agus Darmawan \\ Kementerian BUMN \\ agus.gic@gmail.com
}

\begin{abstract}
The research aims to find the right perspective in the legal accountability of State-owned enterprises management. This research uses a normative approach. The results show that the national legal regulations have not provided clarity in regulations in the management of State-owned enterprises. The transformation of public finance into private finance is the key and clear line of demarcation to understand State-owned enterprises management in the perspective of state financial law, thereby fostering high confidence for Directors in managing State-owned enterprises in the principles of Good Corporate Governance
\end{abstract}

Keywords: State-owned enterprises, Law Transformation, State Finance DOI : https://doi.org/10.31943/yustitia.v6i2.121

\section{PENDAHULUAN}

Berdasarkan Undang-Undang Nomor 17 Tahun 2003 tentang Keuangan Negara ("UU Keuangan Negara”), keuangan Badan Usaha Milik Negara (BUMN) termasuk dalam cakupan keuangan negara sehingga pengelolaan dan pertanggungjawabannya mengikuti mekanisme pengelolaan dan pertanggungjawaban keuangan negara. Dalam rezim keuangan negara, keuangan BUMN termasuk dalam kategori kekayaan negara yang dipisahkan. Sebagai rezim keuangan negara, maka pemeriksaan atas pengelolaan keuangan BUMN menjadi tanggung jawab Badan Pemeriksa Keuangan sebagaimana diatur dalam ketentuan Pasal 6 ayat (1) Undang-Undang Nomor 15 Tahun 2006 tentang Badan Pemeriksa Keuangan (“UU BPK”)'.

Pemeriksaan dan pengelolaan pertanggungjawaban keuangan negara termasuk pada BUMN dilakukan oleh BPK berdasarkan lingkup dan tatacara pemeriksaan sebagaimana tertuang dalam Undang-Undang Nomor 15 Tahun 2004 tentang Pemeriksaan Pengelolaan dan Tanggungjawab Keuangan Negara ("UU Pemeriksaan Pengelolaan dan Tanggungjawab Keuangan Negara"). Pemeriksaan Pengelolaan dan tanggungjawab keuangan negara dilakukan untuk memastikan bahwa keuangan negara dikelola secara tertib, taat pada peraturan perundangundangan, efisien, ekonomis, efektif, transparan, dan

\footnotetext{
${ }^{1}$ Lihat Pasal 6 ayat (1) Undang-Undang Nomor 15 Tahun 2006 tentang Badan Pemeriksa Keuangan
} 
bertanggungjawab dengan memperhatikan rasa keadilan dan kepatutan. Dalam melakukan pemeriksaan, BPK dapat saja menemukan unsur kerugian negara pada BUMN. Pengertian kerugian negara sendiri diatur dalam ketentuan Pasal 1 angka 22 UU BPK yang menyatakan bahwa "Kerugian Negara adalah kekurangan uang, surat berharga, dan barang yang nyata dan pasti jumlahnya sebagai akibat perbuatan melawan hukum baik sengaja maupun lalai ${ }^{2}$." Definisi yang sama juga disebutkan dalam Undang-Undang Nomor 1 Tahun 2004 tentang Perbendaharaan Negara (“UU Perbendaharaan Negara”).

Unsur nyata dalam penentuan kerugian negara mengandung dua pengertian yakni secara materiil dan secara formil. Bila merujuk pada UU Perbendaharaan Negara maka kerugian negara tersebut bersifat materiil. Artinya, terdapat kerugian yang telah nyata terjadi. Sedangkan bila mendasarkan pada ketentuan Pasal 2 ayat (1) Undang-Undang Nomor 31 Tahun 1999 tentang Pemberantasan Tindak Pidana Korupsi ("UU Tipikor"), kerugian negara merupakan delik formil yang artinya terdapatnya potensi timbulnya kerugian negara dapat dikualifisir sebagai telah terjadinya kerugian negara ${ }^{3}$.

Permasalahan yang muncul terkait paradigma keuangan negara pada BUMN adalah menyangkut pertanggungjawaban hukum pengelolaan keuangan BUMN sebagai keuangan negara pada satu sisi dan tata kelola BUMN yang didasarkan pada mekanisme korporasi berdasarkan prinsipprinsip tata kelola perusahaan yang baik atau yang dikenal dengan good corporate governance (GCG) pada sisi lainnya.

Perspektif tanggung jawab hukum pengelolaan keuangan negara dinilai berdasarkan berbagai peraturan perundang-undangan di bidang hukum publik seperti, setidaknya, UU Keuangan Negara, UU BPK, UU tentang Pemeriksaan Pengelolaan Tanggung Jawab Keuangan Negara, UU Perbendaharaan Negara dan Undang-Undang Nomor 19 Tahun 2003 tentang Badan Usaha Milik Negara (“UU BUMN”)". Sementara mekanisme korporasi diatur berdasarkan hukum privat yakni setidaknya dalam UU Nomor 40 Tahun 2007 tentang Perseroan Terbatas (“UU PT”)

Perbedaan rezim pengaturan tersebut menimbulkan perbedaan paradigma dalam memandang tanggung jawab hukum pengelolaan keuangan negara pada BUMN, khususnya dalam hal terjadinya pengambilan keputusan oleh direksi dalam menjalankan perseroan yang menyebabkan timbulnya kerugian pada BUMN bersangkutan.

\footnotetext{
2 Lihat Pasal 1 angka 22 Undang-Undang Badan Pemeriksa Keuangan

${ }^{3}$ Lihat Pasal 2 ayat (1) Undang-Undang Nomor 31 Tahun 1999 tentang Pemberantasan Tindak Pidana Korupsi.

${ }^{4}$ Lihat Undang-Undang Nomor 19 Tahun 2003 tentang Badan Usaha Milik Negara.

${ }^{5}$ Lihat UU Nomor 40 Tahun 2007 tentang Perseroan Terbatas.
} 
Berdasarkan paradigma keuangan negara, maka kerugian BUMN dalam menjalankan usahanya dapat dianggap sebagai kerugian negara (state loss) dan dapat dikualifikasi sebagai tindak pidana korupsi. Sedangkan, bila alur pikirnya mengikuti paradigma pengelolaan BUMN berdasarkan mekanisme korporasi maka kerugian yang terjadi dapat dikualifisir sebagai kerugian usaha (business loss). Terhadap kerugian usaha tersebut, berdasarkan hukum korporasi, direksi dilindungi oleh prinsip business judgement rules ("BJR"). Kerugian yang terjadi dapat saja berakibat pada gugatan perdata, namun direksi terlindungi dari tuntutan pidana. Perbedaan paradigma ini menimbulkan konsekuensi hukum yang berbeda terkait dengan pertanggungjawaban hukum direksi ${ }^{6}$.

Perbedaan perspektif dalam memandang terjadinya kerugian ini menjadi persoalan hukum konkrit yang dihadapi BUMN sebab direksi BUMN dapat dipidana bila terjadi kerugian pada BUMN. Ancaman pidana ini dapat dilakukan sebab keuangan BUMN merupakan keuangan negara sehingga kerugian BUMN dapat menjadi kerugian negara yang dapat diancam dengan pidana korupsi. Namun, persepktif good corporate governance yang memposisikan BUMN tunduk pada UU Perseroan Terbatas menjadikan direksi BUMN dilindungi oleh BJR yang secara normatif juga telah diatur dalam UU Perseroan Terbatas. Dalam ketentuan Pasal 97 ayat (5) UU Perseroan terbatas disebutkan bahwa anggota direksi tidak dapat dimintakan pertanggungjawaban atas kerugian yang terjadi pada perseroan apabila dapat dibuktikan bahwa: i) kerugian tersebut bukan karena kesalahan atau kelalaiannya; ii) telah melakukan pengurusan dengan itikad baik dan kehati-hatian untuk kepentingan dan sesuai dengan maksud dan tujuan perseroan; iii) tidak mempunyai benturan kepentingan baik langsung maupun tidak langsung atas tindakan pengurusan yang mengakibatkan kerugian; iv) telah mengambil tindakan untuk mencegah timbul atau berlanjutnya kerugian tersebut ${ }^{7}$.

Terdapat tumpang tindih antara persoalan kerugian negara dan kerugian bisnis yang berdampak pada pertanggungjawaban hukum direksi. Bila kerugian yang terjadi pada BUMN dipandang semata sebagai kerugian negara maka dampak yang dapat terjadi adalah tidak bebasnya direksi dalam mengambil keputusan bisnis karena adanya kekhawatiran bahwa keputusan tersebut akan berdampak pada timbulnya kerugian BUMN yang kemudian menjadi kerugian negara yang dapat disidik dengan delik korupsi. Sementara, apabila dipandang sebagai kerugian bisnis saja, maka akan berpotensi mendistorsi fungsi

\footnotetext{
6 Helmi Kasim, Rethinking the Supervision of State-Owned Enterprises Based on Business Judgement Rules, Jurnal Konstitusi, Volume 14, Nomor 2, Juni 2017.

7 Lihat Pasal 97 ayat (5) UU Nomor 40 Tahun 2007 tentang Perseroan Terbatas.
} 
BUMN sebagai kepanjangan tangan negara dalam mengelola sumber daya-sumber daya yang penting bagi negara dan yang menguasai hajat hidup orang banyak ${ }^{8}$. Alasan kerugian bisnis juga dapat menjadi tameng untuk bersembunyi dari konsekuensi akibat keputusan bisnis yang diambil dengan mengabaikan prinsip kehati-hatian. Beberapa direksi BUMN didakwa melakukan tindak pidana korupsi atas langkah yang mereka ambil yang berakibat pada terjadianya kerugian pada korporasi ${ }^{9}$.

Persoalan keuangan negara selalu terkait dengan dua hal yakni pengelolaan keuangan dan pertanggungjawabannya. Dua hal ini merupakan aspek pokok yang sudah diatur sejak berlakunya Indische Comptabiliteitswet 1925 (ICW 1925) yang merupakan landasan hukum pengaturan keuangan negara pada zaman Hindia Belanda.

Mahkamah Konstitusi ("MK") telah mengeluarkan putusan mengenai status keuangan negara pada BUMN. Dalam putusan MK putusan Mahkamah Konstitusi Nomor 62/PUU-XI/2013 menegaskan bahwa keuangan BUMN merupakan keuangan negara. Namun, MK juga menyatakan dalam putusan tersebut bahwa paradigma pengawasan negara terhadap BUMN harus diubah. Pengawasan pada BUMN tidak lagi didasarkan pada pengelolaan kekayaan negara dalam urusan pemerintahan tetapi berdasarkan paradigma usaha $^{10 .}$

Dari latar belakang sebagaiman telah diuraikan di atas, dimana pemahaman pengelolaan BUMN sebagai bagian dari keuangan negara dan di sisi lain sebagai keuangan publik masih menimbulkan polemik di masyarakat, maka penulisan ini akan meninjau kembali pengelolaan BUMN sebagai transformasi keuangan publik menjadi keuangan privat dalam perspektif keuangan negara.

Tujuan dalam penulisan ini adalah untuk mengkaji pengelolaan BUMN sebagai transformasi keuangan publik menjadi keuangan privat dalam perspektif keuangan negara. Bagaimana kedudukan BUMN dalam perekonomian negara berdasarkan UUD 1945 dan peran BUMN yang di satu sisi merupakan kepanjangan tangan negara dalam melayani kepentingan publik dan di lain sisi sebagai perseroan yang beroperasi untuk mencari untung. Kemudian pengelolaan perseroan dengan paradigma usaha yang di dalamnya mencakup prinsip-prinsip tata kelola perusahaan yang baik (good corporate governance)

\footnotetext{
8 Op.Cit, Helmi Kasim, Rethinking the Supervision of State-Owned Enterprises Based on Business Judgement Rules.

9 Ibid.

${ }^{10}$ Arifin P. Suriaatmadja, Mekanisme Pertanggungjawaban Keuangan Negara. Suatu Tinjauan Yuridis, PT. Gramedia, Jakarta, 1986, hlm. 111.
} 
dan business judgement rules untuk menemukan perspektif yang tepat dalam pertanggungjawaban hukum dalam pengelolaan $\mathrm{BUMN}^{11}$.

\section{METODE}

Sifat penelitian dalam penulisan ini adalah deskriptif yang dilakukan dengan pendekatan yuridis normatif. Jenis dan sumber data yang digunakan adalah data sekunder. Pengumpulan data dilakukan terutama dengan teknik studi dokumen (library research and online research) dengan menginventarisasi data sekunder yang diperlukan, baik berupa bahan hukum primer, sekunder maupun tersier, kemudian melakukan penelusuran sejarahnya dan sinkronisasi antar bahan hukum tersebut.

Bahan hukum primer yang dipergunakan terdiri dari peraturan perundang-undangan terutama yang berkaitan dengan penyusunan peraturan perundang-undangan dan peranan hukum dalam pembangunan ekonomi. Bahan hukum sekunder yang akan digunakan digunakan antara lain berupa: karya ilmiah, hasil penelitian dan literatur yang berkaitan dengan substansi penelitian. Bahan hukum tersier, yaitu bahan-bahan yang menunjang informasi bahan hukum primer dan sekunder, antara lain data dari surat kabar, jurnal, kamus, ensiklopedia.

\section{HASIL DAN PEMBAHASAN}

Keterlibatan Negara baik secara langsung maupun tidak langsung melalui entitas atau badan-badan hukumnya termasuk di dalamnya BUMN dalam aktifitas komersial sudah berlangsung sejak lama. Pada umumnya aktifitas komersial bergerak di berbagai bidang, seperti pertambangan, elektronik, perkebunan, transportasi, pengairan, penyediaan dan pemeliharaan berbagai fasilitas publik dan lain-lain ${ }^{12}$.

BUMN merupakan badan usaha yang seluruh atau sebagian besar modalnya dimiliki oleh negara, melalui penyertaan secara langsung yang berasal dari kekayaan negara yang dipisahkan. BUMN memiliki kedudukan dan peran penting dalam pengelolaan sumber daya dan produksi barang yang menguasai hajat hidup orang banyak. Pembentukan BUMN dimaksudkan untuk mewujudkan tujuan bernegara, yaitu untuk menciptakan kesejahetraan umum.

Pergeseran paradigma ekonomi publik (peran pemerintah dalam memotori gerak ekonomi sangat menonjol) ke dalam ekonomi pasar (manajemen ekonomi dilandaskan

\footnotetext{
${ }^{11}$ Loc.Cit, Helmi Kasim.

${ }^{12}$ Mihai Mutascu, The effect of Government Intervention in Economy on Corruption, Eurasian Journal of Business and Economy, 2009, 3 (2), hlm. 75-79.
} 
pada mekanisme pasar dan persaingan) telah menggejala di seantero dunia saat ini. Dengan meletakkan landasan operasi pada mekanisme pasar dan persaingan diharapkan akan memacu individu dan badan usaha termasuk di dalamnya BUMN untuk kreatif, inovatif dan terus berinisiatif dengan basis entrepreneurship dan cost efficiency ${ }^{13}$.

BUMN bertujuan memperoleh keuntungan dan mengemban beberapa tugas yang lebih bersifat makro, seperti menjaga stabilitas ekonomi/harga, dan untuk memenuhi sifat penugasan layanan publik atau agent of development serta pioneeringKeterlibatan Negara baik secara langsung maupun tidak langsung melalui entitas atau badan-badan hukumnya termasuk di dalamnya BUMN dalam aktifitas komersial sudah berlangsung sejak lama. Pada umumnya aktifitas komersial bergerak di berbagai bidang, seperti pertambangan, elektronik, perkebunan, transportasi, pengairan, penyediaan dan pemeliharaan berbagai fasilitas publik dan lain-lain.

BUMN merupakan badan usaha yang seluruh atau sebagian besar modalnya dimiliki oleh negara, melalui penyertaan secara langsung yang berasal dari kekayaan negara yang dipisahkan. BUMN memiliki kedudukan dan peran penting dalam pengelolaan sumber daya dan produksi barang yang menguasai hajat hidup orang banyak. Pembentukan BUMN dimaksudkan untuk mewujudkan tujuan bernegara, yaitu untuk menciptakan kesejahteraan umum.

Dalam konteks pengaturan BUMN, sebagai suatu badan usaha sebenarnya memiliki undang-undang tersendiri yang khusus mengatur tentang BUMN, yaitu Undang-Undang Nomor 19 Tahun 2003 tentang BUMN. Selain undang-undang tersebut terdapat undangundang lainnya dan juga peraturan perundang-undangan lain yang berlaku dan mengikat BUMN. Sebagai contoh Undang-Undang tentang Perseroan Terbatas berlaku bagi BUMN yang berbentuk Persero, UndangUndang Nomor 8 Tahun 1999 tentang Pasar Modal berlaku bagi BUMN yang berbentuk PT Persero Tbk, dan peraturan perundang-undangan bidang sektoral yang akan mengikat bagi BUMN yang menjalankan bisnisnya dalam bidang tersebut.

Idealnya regulasi yang mengikat bagi BUMN tersebut bersifat harmonis, dalam arti tidak bertentangan satu sama lainnya. Selain itu juga, seharusnya setiap regulasi yang

\footnotetext{
${ }^{13}$ Elisabeth Nurhaini Butarbutar, Implementation of Good Faith Principles as an Efforts to Prevent the Business Disputes, Journal of Advanced Researrch in Law and Economics, 2020, 11 (4), hlm. 155-179.
} 
mengikat BUMN dapat mendukung agar BUMN dapat optimal dalam menjalankan aktivitas bisnisnya ${ }^{14}$.

Salah satu pokok permasalahan dalam praktik saat ini terkait dengan berlakunya regulasi yang mempengaruhi aktivitas BUMN adalah mengenai kekayaan BUMN. Pengaturan status kekayaan BUMN ini terdapat dalam 2 rezim masing-masing berjalan sektoral, yaitu rezim hukum korporasi dan rezim hukum keuangan negara.

Menurut rezim hukum korporasi, BUMN sebagai sebuah badan usaha yang berbadan hukum memiliki kekayaan yang terpisah dari kekayaan pemiliknya. Kekayaan BUMN berasal dari kekayaan negara yang dipisahkan. Prinsip hukum korporasi, menyatakan bahwa kekayaan yang dipisahkan pada perusahaan harus terlepas dari pemiliknya. Jadi dengan demikian seharusnya kekayaan BUMN tidak dikategorikan sebagai keuangan negara yang memiliki konsekuensi lainnya bagi BUMN. Dalam regulasi yang ada dan menganut rezim hukum korporasi, misalnya UU BUMN. Hal ini tampak dalam Pasal 1 angka 1 Undang-Undang BUMN yang menyebutkan bahwa: "Badan Usaha Milik Negara yang selanjutnya disebut BUMN, adalah badan usaha yang seluruh atau sebagian modalnya dimiliki oleh negara melalui penyertaan secara langsung yang berasal dari kekayaan negara yang dipisahkan." Selanjutnya ketentuan Pasal 4 ayat (1) UndangUndang BUMN menyatakan bahwa: "Modal BUMN merupakan dan berasal dari kekayaan negara yang dipisahkan."

Berdasarkan kedua ketentuan dalam UndangUndang BUMN tersebut, dinyatakan secara tegas bahwa modal BUMN berasal dari kekayaan negara yang dipisahkan. Dengan demikian seharusnya apabila kekayaan negara yang dijadikan modal untuk BUMN tersebut telah dipisahkan, maka kekayaan negara tersebut menjadi kekayaan milik BUMN sebagai badan hukum yang memiliki kekayaan terpisah dari para pemiliknya. Hal tersebut juga dikuatkan dengan penjelasan Pasal 4 ayat (1) UndangUndang BUMN yang menyatakan: "Yang dimaksud dengan dipisahkan adalah pemisahan kekayaan negara dari Anggaran Pendapatan dan Belanja Negara (APBN) untuk dijadikan penyertaan modal negara pada BUMN untuk selanjutnya pembinaan dan pengelolaannya tidak lagi didasarkan pada sistem APBN. Pembinaan dan pengelolaannya didasarkan pada prinsip-prinsip perusahaan yang sehat."

Pengaturan dalam Undang-Undang BUMN tampak sesuai dengan pandangan rezim hukum korporasi. Pandangan berbeda dikemukakan oleh rezim hukum keuangan negara,

\footnotetext{
${ }^{14}$ Hughes, Owen E., Public Management and Administration -An Introduction, St. Martin's Press Inc, New York, 1994, hlm 57-63.
} 
yang pada intinya menyatakan bahwa kekayaan BUMN termasuk ke dalam keuangan negara. Pendapat tersebut dapat diketahui dalam beberapa peraturan perundanganundangan yang berlaku. Salah satu regulasi yang menganut rezim tersebut adalah Undang-Undang Nomor 17 Tahun 2003 tentang Keuangan Negara (selanjutnya disingkat UU Keuangan Negara). Dalam Pasal 1 angka 1 UU Keuangan Negara disebutkan bahwa: "Keuangan Negara adalah semua hak dan kewajiban negara yang dapat dinilai dengan uang, serta segala sesuatu baik berupa uang maupun berupa barang yang dapat dijadikan milik negara berhubung dengan pelaksanaan hak dan kewajiban tersebut ${ }^{15}$."

Pada Pasal 2 Undang-Undang Keuangan Negara, yang menyatakan: "Keuangan negara sebagaimana dimaksud dalam Pasal 1 angka 1, meliputi: kekayaan negara/kekayaan daerah yang dikelola sendiri atau oleh pihak lain berupa uang, surat berharga, piutang, barang, serta hak-hak lain yang dapat dinilai dengan uang, termasuk kekayaan yang dipisahkan pada perusahaan negara/perusahaan daerah ${ }^{16}$."

Berdasarkan ketentuan Undang-Undang Keuangan Negara tersebut, maka keuangan BUMN termasuk dalam lingkup keuangan negara. Demikian juga dengan kekayaan, aset dan kerugian BUMN termasuk juga dalam lingkup keuangan negara, sehingga tindakan yang merugikan BUMN dianggap juga sebagai tindakan yang merugikan negara.

Regulasi lain yang menganut rezim hukum keuangan negara, yaitu Undang-Undang Nomor 31 Tahun 1999 tentang Pemberantasan Tindak Pidana Korupsi (selanjutnya disingkat UU Tipikor). Dalam Bagian Penjelasan Umum UU Tipikor disebutkan bahwa: "Keuangan negara yang dimaksud adalah seluruh kekayaan negara dalam bentuk apapun, yang dipisahkan atau yang tidak dipisahkan, termasuk di dalamnya segala bagian kekayaan negara dan segala hak dan kewajiban yang timbul karena: i) berada dalam penguasaan, pengurusan, dan pertanggungjawaban pejabat lembaga negara, baik di tingkat pusat maupun di daerah; dan ii) berada dalam penguasaan, pengurusan, dan pertanggungjawaban BUMN, yayasan, badan hukum, dan perusahaan yang menyertakan modal negara, atau perusahaan yang menyertakan modal pihak ketiga berdasarkan perjanjian dengan negara.

Berdasarkan Bagian Penjelasan Umum UU Tipikor tersebut, maka kekayaan BUMN termasuk juga dalam lingkup keuangan negara. Dengan demikian tindakan yang merugikan BUMN dianggap sebagai tindak pidana korupsi.

\footnotetext{
${ }^{15}$ Lihat Pasal 1 angka 1 Undang-Undang Nomor 17 Tahun 2003 tentang Keuangan Negara.

${ }^{16}$ Lihat Pasal 2 Undang-Undang Nomor 17 Tahun 2003 tentang Keuangan Negara.
} 
Dalam ketentuan Pasal 1 angka 7 UU BPK Undang-Undang Nomor 15 Tahun 2006 tentang Badan Pemeriksa Keuangan (selanjutnya disingkat UU BPK), disebutkan bahwa: "Keuangan Negara adalah semua hak dan kewajiban negara yang dapat dinilai dengan uang, serta segala sesuatu baik berupa uang maupun berupa barang yang dapat dijadikan milik negara berhubung dengan pelaksanaan hak dan kewajiban tersebut ${ }^{17}$."

Berdasarkan pengertian di atas, maka tampak adanya kesamaaan pandangan dengan yang telah diberikan oleh pengertian keuangan negara sebagaimana yang terdapat dalam Undang-Undang Keuangan Negara. Dengan demikian BPK berwenang untuk melakukan pemeriksaan terhadap keuangan negara pada BUMN.

Tampak sekali dari kedua regulasi tersebut di atas adanya kontradiksi peraturan perundangundangan yang mengatur tentang BUMN khususnya mengenai kedudukan kekayaan BUMN. Dalam mengatasi permasalahan seperti ini, teori hukum harus memberikan jawaban dengan asas hukum. Adanya pertentangan antara 2 peraturan perundangundangan dalam mengatur objek masalah hukum yang sama dijawab oleh asas hukum. Apabila terdapat pertentangan pengaturan terhadap suatu masalah hukum, maka ketentuan yang bersifat khusus mengesampingkan ketentuan yang bersifat umum, sesuai asas lex specialis derogat legi generalis ${ }^{18}$.

Pada dasarnya BUMN yang berbentuk Persero atau PT (Persero) sama sebagai PT biasa, seperti halnya PT-PT yang lain. Adapun kekhususannya berdasarkan ketentuan Undang-Undang BUMN, modal yang terbagi dalam saham itu seluruh atau paling sedikit $51 \%$ (lima puluh satu persen) dimiliki oleh negara, yang bertujuan untuk mengejar keuntungan (profit oriented). PT (Persero) adalah suatu entitas hukum mandiri, yang mempunyai persona standi in judicio. Menurut rezim hukum korporasi, kedudukan negara di sini berstatus sebagai pemegang saham, bukan sebagai negara lagi.

Hukum harus memperlakukan BUMN sama dengan PT biasa. Tidak boleh membedakan kedudukan BUMN sebagai badan hukum publik yang tunduk pada peraturan perundang-undangan yang bersifat publik dan BUMN sebagai badan hukum privat, tunduk pada ketentuan hukum privat.

Negara tidak memiliki keleluasan untuk mengeluarkan wewenang yang bersifat publik dalam pengelolaan sektor privat yang tata kelola dan tata tanggung jawabnya tunduk pada ketentuan privat. Dalam hal ini pemerintah sebagai representasi pemilik

\footnotetext{
${ }^{17}$ Lihat Pasal 1 angka 7 Undang-Undang Nomor 15 Tahun 2006 tentang Badan Pemeriksa Keuangan.

${ }^{18}$ Shinta Agustina, Implementasi Asas Lex Specialis Derogat Legi Generali Dalam Sistem Peradilan Pidana, urnal Masalah-Masalah Hukum, Vol (4), (44), 2015, hlm. 25-36.
} 
saham BUMN (Persero) diminta menyadari tanggung jawab atas risiko kepemilikan saham yang diakui sebagai kekayaan negara.

Sudah sejak awal dalam peraturan perundangundangan memperlakukan BUMN sebagai suatu unit usaha yang profit oriented. Dengan demikian, BUMN harus dapat menjalankan perusahaan itu secara profesional. Pada saat ini BUMN masih belum diberi kebebasan penuh dalam menjalankan bisnisnya secara profesional. Dengan regulasi yang ada dalam opersional BUMN yang dijalankan oleh manajemen BUMN timbul suatu keadaan dan risiko besar yang harus dipikul karena dianggap mengelola uang negara. Manajemen BUMN tidak memiliki kebebasan lazimnya dalam menjalankan suatu usaha secara profesional karena risiko apabila dalam menjalankan bisnis mendatangkan kerugian pada perusahaan dapat dianggap merugikan keuangan negara dan dijerat tindak pidana korupsi. Manajemen BUMN dalam menjalankan bisnis seharusnya memiliki keleluasaan di dalam membuat keputusan bisnis yang profesional, karena tindakannya akan terlindungi oleh doktrin Bussiness Judgement Rules. Apabila dalam menjalankan bisnis mendatangkan kerugian pada perusahaan dapat dianggap merugikan keuangan negara dan dijerat tindak pidana korupsi. Manajemen BUMN dalam menjalankan bisnis seharusnya memiliki keleluasaan di dalam membuat keputusan bisnis yang profesional, karena tindakannya akan terlindungi oleh doktrin Bussiness Judgement Rules.

Sementara itu, konsep BJR yang berisi prinsip-prinsip perlindungan terhadap direksi dalam pengambilan keputusan juga dikenal dalam hukum perseroan. Dalam pengelolaan perseroan, pengurus perseroan, dalam hal ini direksi dilindungi oleh BJR dalam pengambilan keputusan bisnis untuk kepentingan perseroan. Hakekat BJR adalah bahwa bila direksi telah mengambil keputusan dengan hati-hati dan berdasarkan itikad baik maka keputusannya dianggap sebagai keputusan bisnis (business judgement) dan direksi tidak dapat dimintai pertanggungjawaban meskipun bila keputusan tersebut menimbulkan kerugian pada perseroan ${ }^{19}$.

Paradigma BJR ini juga telah ditegaskan oleh Mahkamah Konstitusi dalam putusannya untuk diterapkan dalam pengawasan BUMN. Mahkamah Konstitusi berpendapat bahwa meskipun kewenangan negara di bidang pengawasan tetap berlaku karena keuangan BUMN adalah keuangan negara, namun, paradigma pengawasan tersebut harus berubah yakni bukan lagi berdasarkan paradigma pengelolaan keuangan negara dalam pemerintahan tetapi berdasakan paradigma usaha.

\footnotetext{
${ }^{19}$ Pramagitha, P \& Sukranatha, K., Prinsip Business Judgment Rule Sebagai Upaya Perlindungan Terhadap Keputusan Bisnis Direksi BUMN, 2019, 7 (12), hlm. 1-14.
} 
Tata kelola perusahaan yang baik dapat dipandang baik dari perspektif hukum dengan teori hukum maupun perspektif ekonomi dengan teori ekonomi meskipun sebenarnya agak sulit untuk menarik garis pemisah di antara keduanya. Baik teori hukum maupun teori ekonomi telah saling mempengaruhi ${ }^{20}$. Menurut Guhan Subramanian, wacana mengenai corporate governance telah muncul pada tahun 1930an melalui karya Adolf Berle dan Gardiner Means namun berkembang sampai pada tahap sebagaimana dipahami sekarang pada tahun 1970an. Karya Berle dan Means mengetengahkan wacana tentang korporasi di abad $20^{21}$.

Pengakuan terhadap kekayaan negara hasil dari pemisahan dari APBN pada BUMN tetap harus tunduk dan berlaku Undang-Undang Nomor 40 Tahun 2007 tentang Perseroan Terbatas. Intinya, kekayaan negara yang sudah disertakan sebagai modal BUMN yang dapat disita karena kekayaan itu bukan lagi milik negara melainkan sudah menjadi harta miliki BUMN. "Status harta ini tunduk pada UndangUndang Nomor 40 Tahun 2007 tentang Perseroan Terbatas dan dikelola oleh perseroan berdasarkan prinsip-prinsip pengelolaan perusahaan yang sehat.”

BUMN harus tetap menjadi bagian dari keuangan negara, namun agar BUMN bisa berkembang perlu diberikan otonomi dalam pengelolaannya yaitu mengikuti kaidah-kaidah bisnis yang sehat, termasuk mengikuti ketentuan undang-undang perseroan. Kekayaan negara pada BUMN harus terpisah dari APBN agar kekayaannya dapat dikelola sesuai dengan prinsip-prinsip bisnis yang sehat dan efisien untuk sebesar-besarnya kemakmuran rakyat $^{22}$. Lebih lanjut dinyatakan bahwa maksud pengertian kekayaan negara yang dipisahkan pada BUMN adalah dipisah dari sistem pencatatan dan pengelolaan APBN. Walaupun demikian, keuangan yang berasal dari APBN dipisahkan dari BUMN tetap merupakan bagian dari kekayaan negara, aset negara, dan keuangan negara.

Undang-Undang Keuangan Negara berdampak tidak ada kepastian hukum bagi pelaksana Undang-Undang BUMN dan undang-undang terkait. Kondisi ini mengungkap fakta bahwa Direksi BUMN dibayang-bayangi kekhawatiran dari keputusan bisnis yang jujur dan akuntabel, tetapi dituduh korupsi karena mengakibatkan kerugian negara. Hal ini tidak tepat jika kekayaan negara yang dipisahkan menjadi modal BUMN masih dikategorikan sebagai bagian keuangan negara seperti diatur Undang-Undang Keuangan

${ }^{20}$ Petri Mäntysaari, Organising the Firm. Tehories of Commercial Law, Corporate Governance and Corporate Law, Verlag Berlin Heidelberg, Springer, 2012, hlm. 75.

${ }^{21}$ Thomas Clarke and Douglas Branson, eds., The Sage Handbook of Corporate Governance, London, California, New Delhi, Singapore: SAGE Publications, 2012, hlm. 1.

${ }^{22}$ Bambang, U, Marimin. I, Agung P, Improving Performance of Indonesia State-Owned Enterprises Holding, Policies and Strategies, Asian Journal of Applied Sciences, , Vol (7), No (5), 2019, hlm. 686-694. 
Negara. Pengurus BUMN bukan penyelenggara negara, melainkan organ BUMN seperti halnya direksi-direksi perusahaan lainnya ${ }^{23}$.

Menurut ketentuan di dalam Pasal 2 huruf g Undang-Undang Perbendaharaan Negara juga dikatakan bahwa: "Keuangan Negara sebagaimana dimaksud di dalam Pasal 1 Angka (1) tersebut meliputi: kekayaan negara/daerah yang dikelola sendiri atau oleh pihak lain berupa uang, surat berharga, piutang, barang serta hak-hak lain yang dapat dinilai dengan uang, termasuk kekayaan yang dipisahkan pada perusahaan negara/perusahaan daerah”. Sementara itu Undang-Undang BUMN menegaskan bahwa PT ( Persero ) dalam melakukan kegiatan usahanya tunduk pada Undang-UndangMenurut ketentuan di dalam Pasal 2 huruf g Undang-Undang Perbendaharaan Negara juga dikatakan bahwa: "Keuangan Negara sebagaimana dimaksud di dalam Pasal 1 Angka (1) tersebut meliputi: kekayaan negara/daerah yang dikelola sendiri atau oleh pihak lain berupa uang, surat berharga, piutang, barang serta hak-hak lain yang dapat dinilai dengan uang, termasuk kekayaan yang dipisahkan pada perusahaan negara/perusahaan daerah". Sementara itu Undang-Undang BUMN menegaskan bahwa PT (Persero) dalam melakukan kegiatan usahanya tunduk pada Undang-Undang Nomor 40 tahun 2007 Tentang Perseroan Terbatas. Dengan demikian segala kebijakan sektoral terkait dengan aksi korporasi atau dalam rangka business judgement yang dilakukan oleh Direksi PT (Persero) berlaku secara equal bagi semua entitas bisnis baik PT Swasta maupun PT (Persero) seperti misalnya pengaturan dan/atau penyusunan RKAP, penentuan dan/atau penunjukan auditor perseroan, pengaturan mengenai pengadaan barang dan jasa, penghapusan aset perseroan, penghapusan piutang dan sebagainya. Semua ini adalah ranah business judgement rule Perseroan.

Namun yang terjadi saat ini selalu timbul kekhawatiran dari Direksi PT (Persero) bahwa dalam membuat keputusan bisnis selalu dibayang-bayangi akan timbulnya ekses negatif terkait dengan keputusan bisnis yang dijalankan. Mereka paham sekali bahwa dalam membuat keputusan bisnis tidak ada satupun direksi yang mampu memastikan bahwa keuntungan yang diprediksikan akan diperoleh melalui perhitungan-perhitungan bisnis yang akurat, wajar dan akuntabel sesuai dengan standard operation procedure (SOP) yang telah ditetapkan, sesuai dengan prinsip kehati-hatian dan dilandasi oleh prinsip itikad baik dengan mengedepankan prinsip-prinsip good corporate governance.

\footnotetext{
${ }^{23}$ Ahmad, M, Sopian S, Muhamad M, Pertanggungjawaban Pimpinan BUMN/BUMD Berbentuk Perseroan Terbatas dalam Penyelesaian Tindak Pidana Korupsi, Jurnal Ilmiah Hukum de Jure, 2019, Vol (1), No (1), hlm. 65-83.
} 
Keuntungan tersebut akan benar benar atau pasti akan diperoleh sesuai dengan prediksi tersebut ${ }^{24}$.

Tidak semua Direksi Persero paham mengenai konsepsi BJR. Bisa dimaklumi karena tidak semuanya bahkan mayoritas tidak berlatar belakang pendidikan hukum. Walaupun ada Biro Hukum di perseroan tersebut namun tidak memahami pengetahuan tentang hukum bisnis, maka dapat dipastikan juga tidak akan memahami ketidakharmonisan beberapa kaedah hukum sebagaimana diuraikan di atas. Oleh sebab itu tidak heran jika dibaca di media-media, BUMN di Indonesia sering dibandingkan dengan BUMN negara-negara tetangga yang sangat jauh dalam pencapaian revenue-nya.

Dari rezim hukum publik, ada dua undang-undang yang mengklaim bahwa kekayaan BUMN itu termasuk kekayaan negara, yakni Undang Undang Keuangan Negara dan Undang-Undang Perbendaharaan Negara. Padahal dari kacamata hukum privat, yang disebut pelaku usaha baik badan hukum publik atau privat, kalau melaksanakan bisnis harus tunduk kepada rezim hukum bisnis.

Harta kekayaan BUMN atau BUMD dapat disita oleh pengadilan. Terhadap keuangan negara yang disertakan inbreng (penyertaan modal) dalam BUMN atau BUMD persero dapat disita, demikian bunyi kesimpulan yang dihasilkan oleh Bidang Perdata Umum. Namun tidak semua harta kekayaan BUMN atau BUMD yang dapat disita.

Intinya, kekayaan negara yang telah disertakan sebagai modal BUMN atau BUMD dapat disita karena kekayaan itu bukan lagi milik negara melainkan sudah menjadi harta miliki BUMN atau BUMD. Dengan demikian, status harta ini tunduk pada UndangUndang Nomor 40 Tahun 2007 tentang Perseroan Terbatas dan dikelola oleh perseroan berdasarkan prinsip-prinsip pengelolaan perusahaan yang sehat. Pada sisi lain, uang atau barang milik negara yang bukan penyertaan modal tetapi dikelola oleh BUMN atau BUMD tidak dapat dilakukan sita jaminan atau sita eksekusi. Hal ini mengacu kepada pada Pasal 50 UndangUndang Nomor 1 Tahun 2004 tentang Perbendaharaan Negara yang menyatakan bahwa harta kekayaan milik negara tidak bisa disita oleh pengadilan.

\section{PENUTUP}

\subsection{Simpulan}

Berdasarkan analisis terhadap rumusan masalah dalam uraian sebelumnya, maka penulis menyimpulkan bahwa:

\footnotetext{
${ }^{24}$ Taylor, Charles Lewis, Why Government Grow-Measuring Public Sector Size, Sage Publications, Beverly Hills, London, New Delhi, 2002, hlm. 34-40.
} 
1. Regulasi hukum nasional belum memberikan kejelasan regulasi dalam pengelolaan BUMN karena pertentangan dua pandangan terhadap Keuangan Negara yang diikutsertakan pada BUMN atau dalam penyertaan pada BUMN yang berasal dari APBN masih dipertahankan seperti keadaan semula. Pengelolaan BUMN sebagai transformasi keuangan publik menjadi keuangan privat dalam dalam perspektif hukum keuangan negara harus dipahami oleh seluruh stakeholder penyelenggara negara, sehingga diharapkan menumbuhkan kepercayaan yg tinggi dari seorang Direksi dalam menjalankan BUMN.

2. Putusan Mahkamah Konstitusi (MK) Nomor 48/PUU-XI/2013 yang mempertahankan pemikiran bahan Keuangan Negara yang disertakan pada modal BUMN masih dianggap bagian dari Keuangan Negara, bahkan dengan Putusan MK ini memiliki dampak yang luas bagi semua perkara yang terjadi di kemudian hari karena Putusan MK yang bersifat erga omnes. Putusan MK ini menentukan mekanisme pertanggungjawaban hukum pengelolaan keuangan negara pada BUMN berkaitan erat dengan prinsip-prinsip pengelolaan perusahaan yang baik dan bagaimana menilai pertanggungjawaban direksi berdasarkan BJR. Pemeriksaan terhadap BUMN menggunakan prinsip yang berbeda dengan pemeriksaan keuangan negara pada lembaga negara lainnya yang tidak mengelola usaha.

\subsection{Saran}

Berdasarkan analisis terhadap simpulan dalam uraian sebelumnya, maka penulis memberikan saran bahwa:

1. Pengaturan tentang hukum nasional selayaknya dapat memberikan kejelasan regulasi dalam pengelolaan BUMN supaya tidak terjadi pertentangan terhadap dua pandangan terhadap Keuangan Negara yang diikutsertakan pada BUMN atau dalam penyertaan pada BUMN yang berasal dari APBN supaya tidak terus dipertahankan seperti keadaan semula. Tata kelola BUMN yang berperan sebagai transformasi keuangan publik menjadi keuangan privat dalam dalam perspektif hukum keuangan negara harus juga dipahami oleh seluruh stakeholder penyelenggara Negara.

2. Putusan MK merupakan suatu penentu dalam mekanisme pertanggungjawaban hukum pengelolaan keuangan negara pada BUMN serta berkaitan erat dengan prinsip-prinsip pengelolaan perusahaan yang baik dan bagaimana menilai pertanggungjawaban direksi berdasarkan BJR untuk itu perlu diperhatikan pula 
agar rumusan perturan perundang-undangan harus dibahas secara serius dan seksama supaya tidak terjadi tumpang tindih yang mengharuskan tindakan yg memerlukan Putusan dari MK.

\section{DAFTAR PUSTAKA}

\section{A. Buku:}

Arifin P. Suriaatmadja, Mekanisme Pertanggungjawaban Keuangan Negara. Suatu Tinjauan Yuridis, PT. Gramedia, Jakarta, 1986, hlm 111.

Hughes, Owen E., Public Management and Administration -An Introduction, St. Martin's Press Inc, New York, 1994, hlm 57-63.

Mihai Mutascu, The effect of Government Intervention in Economy on Corruption, Eurasian Journal of Business and Economy, 2009, 3 (2), hlm 75-79.

Pramagitha, P \& Sukranatha, K., Prinsip Business Judgment Rule Sebagai Upaya Perlindungan Terhadap Keputusan Bisnis Direksi BUMN, 2019, 7 (12), hlm 114.

Petri Mäntysaari, Organising the Firm. Tehories of Commercial Law, Corporate Governance and Corporate Law, Verlag Berlin Heidelberg, Springer, 2012, hlm 75.

Thomas Clarke and Douglas Branson, eds., The Sage Handbook of Corporate Governance, London, California, New Delhi, Singapore: SAGE Publications, 2012, hlm 1.

Taylor, Charles Lewis, Why Government Grow-Measuring Public Sector Size, Sage Publications, Beverly Hills, London, New Delhi, 2002, hlm 34-40.

\section{B. Jurnal:}

Ahmad, M, Sopian S, Muhamad M, Pertanggungjawaban Pimpinan BUMN/BUMD Berbentuk Perseroan Terbatas dalam Penyelesaian Tindak Pidana Korupsi, Jurnal Ilmiah Hukum de Jure, 2019, Vol (1), No (1), hlm 65-83.

Bambang, U, Marimin. I, Agung P, Improving Performance of Indonesia State-Owned Enterprises Holding, Policies and Strategies, Asian Journal of Applied Sciences, ,Vol (7), No (5), 2019, hlm. 686-694. 
Elisabeth Nurhaini Butarbutar, Implementation of Good Faith Principles as an Efforts to

Prevent the Business Disputes, Journal of Advanced Researrch in Law and Economics, 2020, 11 (4), hlm 155-179.

Shinta Agustina, Implementasi Asas Lex Specialis Derogat Legi Generali Dalam Sistem Peradilan Pidana, Jurnal Masalah-Masalah Hukum, Vol (4), (44), 2015, hlm 2536.

\section{Peraturan:}

Republik Indonesia, Undang-Undang Nomor 1 Tahun 2004 tentang Perbendaharaan Negara

Republik Indonesia, Undang-Undang Nomor 17 Tahun 2003 tentang Keuangan Negara

Republik Indonesia, Undang-Undang Nomor 19 Tahun 2003 tentang Badan Usaha Milik Negara

Republik Indonesia, Undang-Undang Nomor 31 Tahun 1999 tentang Pemberantasan Tindak Pidana Korupsi. 